\title{
Effects of Fin Spacing and Gas Radiation on Heat Transfer in Utility Boiler Economizers
}

\author{
Azad HAMZEHPOUR, Cyrus AGHANAJAFI, Hossein SHOKOUHMAND, Mohammad NAJAFI
}

\begin{abstract}
The aim of this paper is to estimate fin spacing and gas radiation effects on heat transfer in utility boiler economizers to achieve the highest feed water temperature, and the biggest amount of heat transferred from flue gases to economizer tubes. This study is carried out for five different cases including a bare tube economizer and four finned-tube economizers with different fin spacing values. A finite volume method is employed to discretize and solve the governing equations for all cases in 3D. As a result, for verification purpose, the present numerical result is compared to the experimental outputs and it shows that the average Nusselt number difference is $15 \%$. The finnedtube economizer with fin spacing value of $21 \mathrm{~mm}$ absorbs the biggest amount of heat, and it has the highest outlet feed water temperature; therefore, it has the best thermal performance among the other cases. It is also concluded that radiation heat transfer mechanism has a minor effect on heat exchange in utility boiler economizers.
\end{abstract}

Keywords: fin spacing; gas radiation; heat transfer; numerical investigation; utility boiler economizer

\section{INTRODUCTION}

According to the energy crisis, analyzing and optimizing of energy systems are necessary to improve their performances. One of the important mechanical components in most power plants is economizer. Economizer is generally a type of heat exchanger which is used for preheating the boiler feed water before entering the steam drum. By providing such component and installing it, the low level energy is recovered from the flue gas before it is exhausted to the atmosphere and consequently, the amount of fuel consumed to provide steam in boilers is reduced as well. For each $22^{\circ} \mathrm{C}$ that flue gas is cooled at by an economizer, the overall boiler efficiency increases by approximately $1 \%$ [1]. In order to increase heat transfer between the flue gas and the feed water, different types of extended surfaces called fins can be attached to economizer tubes.

Mudafale et al. [2] studied an economizer in a tangential fired boiler numerically and the performance of the economizer was analyzed by using computational fluid dynamics methods. Obual Reddy et al. [3] carried out an analysis of economizer in two cases and found a considerable increment in heat transfer by attaching fins in one of the cases. The more amount of energy transferred to the feed water in that case was due to turbulent flow. Holkar et al. [4] conducted an investigation of gas flow behavior in economizer. It was indicated that pressure drop in a duct with straight vanes decreased by $50 \%$ in comparison with a duct without vanes. However, it was noticed that more pressure drop took place at a duct with curved vanes. Aziz et al. [5] modified overall heat transfer coefficient of an economizer by using genetic algorithm. For this purpose, logarithmic mean temperature difference (LMTD) between flue gas and feed water was calculated.

Optimization of a low pressure economizer with serpentine pipes and square fins was carried out by Wang et al. [6]. Thermal, economic and safety performances were optimized with particle swarm optimization (PSO) algorithm and it was illustrated that the amount of fuel consumption and $\mathrm{CO}_{2}$ emission was reduced by using a low pressure economizer in a $600 \mathrm{MW}$ coal-fired power plant. A thermodynamic investigation of a low pressure economizer also indicated that although the impact on the thermal system after the installation of a low pressure economizer is small, it cannot be neglected [7]. Patil et al. [8] optimized economizer size by reducing the number of tubes. It was depicted that the required water temperature was obtained after the $19^{\text {th }}$ row of economizer tube. There is a variety of optimization techniques such as the response surface and Taguchi Methods. These methods were employed to optimize fin spacing in a finned-tube heat exchanger under frosting conditions and the average heat transfer rate augmented significantly compared to the reference model [9].

Different types of finned-tube heat exchangers used in industries have been studied by many scientists [10-19]. These works include shape optimization, analytical and numerical analysis of finned-tube heat exchangers and tube banks.

One of the aspects of the present study is to determine the effect of radiation heat transfer in comparison with convection heat transfer. This effect has been considered in a few studies in the literature and it is mostly assumed to be zero. Taler et al. [20] developed a new formula for estimating the radiation heat transfer coefficient in superheaters. It was shown that the maximum deviation between the results obtained by using this formula and CFD simulation is $12,5 \%$. Moghari et al. [21] employed zonal method to assess thermal radiation behavior within a D-type water-cooled steam boiler. The estimation of radiation and convection heat transfer coefficients in different equipment in boilers, such as economizer, was obtained by using zonal method.

The goal of the present study is to numerically investigate the effects of fin spacing and gas radiation on heat transfer rate and thermal performance of utility boiler economizers used in power plants. For this purpose, a numerical method is developed to discretize mass, momentum and energy conservation and thermal radiation equations. The impact of fin spacing is analyzed in 5 cases for the economizers with circular fins. The flow regime inside and outside of the tubes of economizer is turbulent. The temperature distributions and heat transfer coefficients are obtained for each case and the results are also compared with the existing outputs from the literature.

\section{GOVERNING EQUATIONS}

It is assumed that the flow in the economizer is steady and three dimensional. The governing equations are as follows: 
$\rho \vec{v}+\nabla \cdot \frac{\partial \rho}{\partial t}=0$

$\frac{\partial}{\partial t}(\rho \vec{v})+\nabla \cdot(\rho \vec{v} \vec{v})=-\nabla p+\nabla \cdot(\overline{\bar{\tau}})+\rho \vec{g}+\vec{F}$,

Where:

$\overline{\bar{\tau}}=\mu\left[\left(\nabla \vec{v}+\nabla \vec{v}^{\mathrm{T}}\right)-\frac{2}{3} \nabla \cdot \vec{v} I\right]$,

$\frac{\partial}{\partial t}(\rho E)+\nabla \cdot(\vec{u}(\rho E+\rho))=$

$=\nabla \cdot\left(K_{e f f} \nabla T-\sum_{j} h_{j} \vec{J}_{j}+\left(\bar{\tau}_{e f f} \cdot \vec{u}\right)\right)+S_{h}$,

Eq. (1), (2), (3) and (4) are mass conservation, momentum conservation, stress tensor and energy conservation respectively. In order to simulate turbulent flow either in tubes or in duct, a modified Navier-Stokes equation is used as follows:

$\frac{\partial}{\partial t}\left(\rho u_{i}\right)+\frac{\partial}{\partial x_{j}}\left(\rho u_{i} u_{j}\right)=$

$=-\frac{\partial p}{\partial x_{i}}+\frac{\partial}{\partial x_{i}}\left[\mu\left(\frac{\partial u_{i}}{\partial x_{j}}+\frac{\partial u_{j}}{\partial x_{j}}-\frac{2}{3} \delta_{i j} \frac{\partial u_{k}}{\partial x_{k}}\right)\right]+\frac{\partial}{\partial x_{j}}\left(-\rho \overline{u_{i}^{\prime} u_{j}^{\prime}}\right)$,

Where:

$-\rho \overline{u_{i}^{\prime} u_{j}^{\prime}}=\mu_{t}\left(\frac{\partial u_{i}}{\partial x_{j}}\right)-\frac{2}{3}\left(\rho k+\mu_{t} \frac{\partial u_{i}}{\partial x_{i}}\right) \delta_{i j}$,

Radiation Transport Equation (RTE) is used to determine the effect of radiation heat transfer in comparison with convection heat transfer. This equation is shown below:

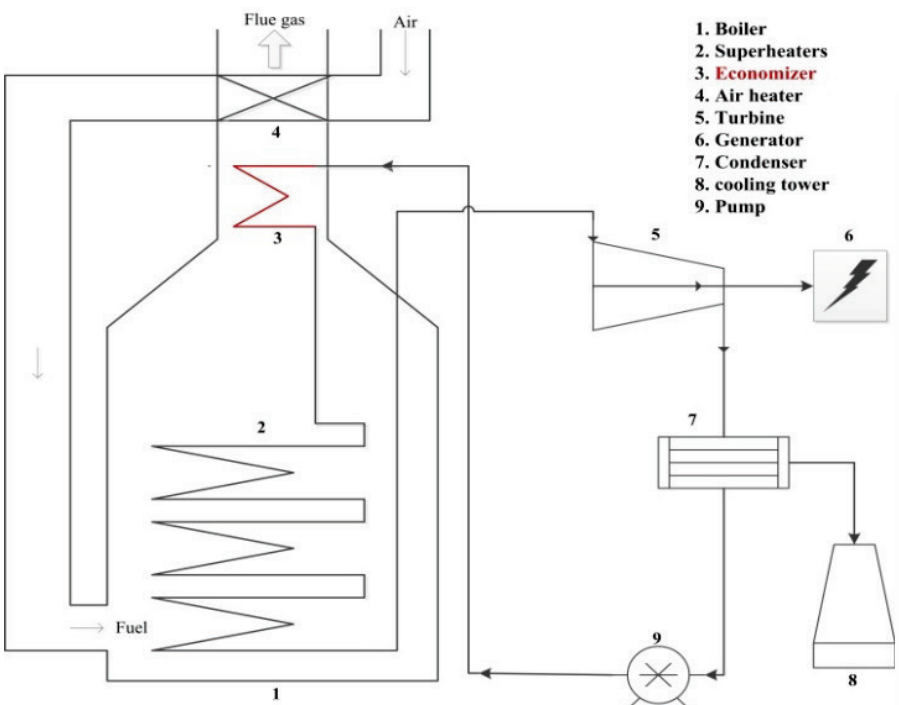

(a)

$$
\begin{aligned}
& \frac{\mathrm{d} I(\vec{r}, \vec{s})}{\mathrm{d} s}+\left(a+\sigma_{s}\right) I(\vec{r}, \vec{s})= \\
& =a n^{2} \frac{\sigma T^{4}}{\pi}+\frac{\sigma_{s}}{4 \pi} \int_{0}^{4 \pi} I(\vec{r}, \vec{s}) \varphi\left(\vec{s}, \vec{s}^{\prime}\right) \mathrm{d} \Omega^{\prime},
\end{aligned}
$$

Where:

$$
I(\vec{r}, \vec{s})=\sum_{k} I_{\lambda_{k}}(\vec{r}, \vec{s}) \Delta \lambda_{k}
$$

Two combustion products that make the most contributions to the thermal radiation are $\mathrm{H}_{2} \mathrm{O}$ and $\mathrm{CO}_{2}$. Thus, the weighted sum of gray gas model (WSGG) has been served to make an accurate approximation of absorptivity and emissivity of these gases. Absorption and emissivity coefficients can be written as follows:

$$
\begin{aligned}
& \alpha_{g}=\sum_{i=0}^{n} \alpha_{s, i}\left(1-\operatorname{Exp}\left(-k_{i} \cdot P L\right)\right), \\
& \varepsilon_{g}=\sum_{i=0}^{n} \alpha_{g, i}\left(1-\operatorname{Exp}\left(-k_{g, i} \cdot P L\right)\right),
\end{aligned}
$$

\section{NUMERICAL PROCEDURE}

In order to discretize the equations above, a finite volume method has been developed in this study. As shown in Fig. 1a, economizer is located in stack where the flue gases go through (this cycle is described in much more details by Van Wylen et al. [22]). Fig. 1b illustrates a 3D schematic diagram of the designed finned-tube bundles of economizer with feed water headers located in a stack. A proper computational domain is considered for investigating the effects of fin spacing on heat transfer rate. Then, the whole space of specified domain is divided using a sufficiently fine grid. Finally, all the equations have been numerically solved for each computational domain in different cases.

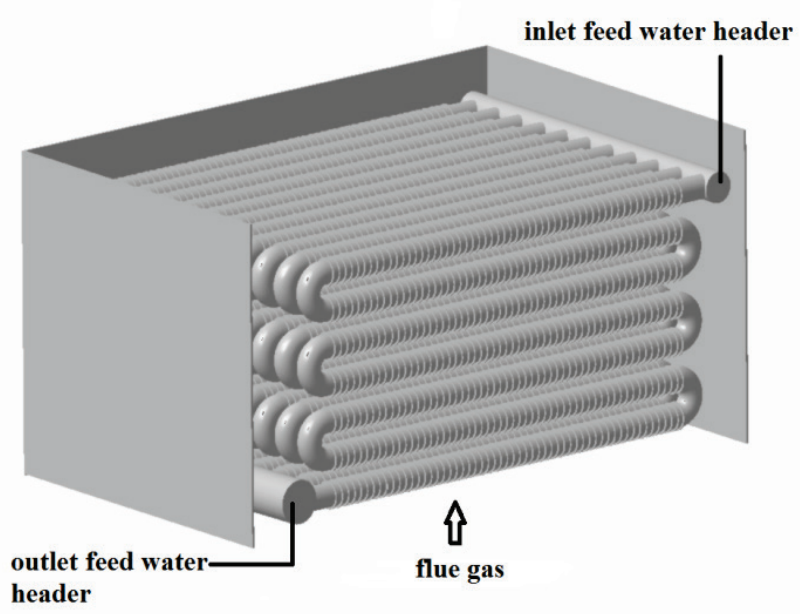

(b)

Figure 1 Schematic diagram of (a) a steam power plant and the location of economizer [22] and (b) designed finned-tube bundles of economizer in a stack

A schematic diagram of a designed finned-tube economizer is represented in Fig. 2. Five different cases including a bare tube economizer and four finned-tube economizers with different fin spacing are analyzed. Each case is considered as a heat exchanger with counter flow. 
All the geometric parameters and dimensions of each case are represented in Tab. 1.

Table 1 Geometric parameters and dimensions of utility boiler economizer for different cases

\begin{tabular}{|l|c|c|c|c|c|}
\hline \multirow{2}{*}{} & \multicolumn{5}{|c|}{ Case number } \\
\cline { 2 - 6 } & I & II & III & IV & V \\
\hline Inside diameter of tubes, $d_{i}(\mathrm{~mm})$ & 44,5 & 44,5 & 44,5 & 44,5 & 44,5 \\
\hline Outside diameter of tubes, $d_{o}(\mathrm{~mm})$ & 53,5 & 53,5 & 53,5 & 53,5 & 53,5 \\
\hline Fin thickness, $t$ & - & 3 & 3 & 3 & 3 \\
\hline Fin height, $h$ & - & 5 & 5 & 5 & 5 \\
\hline Fin spacing, $S_{f}$ & - & 15 & 18 & 21 & 24 \\
\hline Number of tube rows, $N$ & 7 & 7 & 7 & 7 & 7 \\
\hline Number of fins in each row & 37 & 37 & 37 & 37 & 37 \\
\hline
\end{tabular}

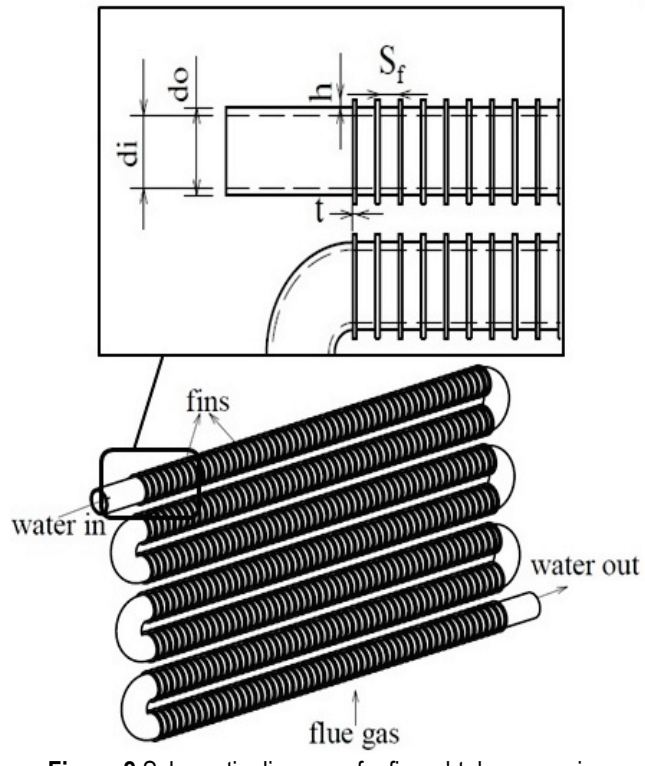

Figure 2 Schematic diagram of a finned-tube econmizer

\section{VALIDATION OF THE PRESENT NUMERICAL METHOD}

For validation of current study, the results are compared with experimental results from the literature.

Proposed correlations made by Babcock and Wilcox Company [1] to determine inside heat transfer coefficient in economizers are employed to validate the achieved results. These correlations are presented below:

$$
\begin{aligned}
& N u_{f d}=\frac{h_{i} d_{i}}{k_{w f}}=0.023 \operatorname{Re}_{w f}^{0.8} \operatorname{Pr}_{w f}^{0.4}\left(\frac{T_{w}}{T_{w f}}\right)^{0.8}, \\
& N u=N u_{f d}\left[1+\left(\frac{d}{x}\right)^{0.7}\right],
\end{aligned}
$$

where all the water properties are calculated at water film temperature:

$T_{w f}=\frac{T_{w}+T_{s}}{2}$

Eq. (11) and (12) are recommended for fully developed turbulent flow and not fully developed turbulent flow respectively.

Nusselt numbers vs. Reynolds numbers is plotted for both numerical method and experimental correlation in Fig. 3 which shows that the present numerical results are in a good agreement with the results of experimental correlation. The maximum difference between the results does not exceed $\pm 20,0 \%$ and the average difference is $15 \%$ which is an acceptable difference for turbulent flow.

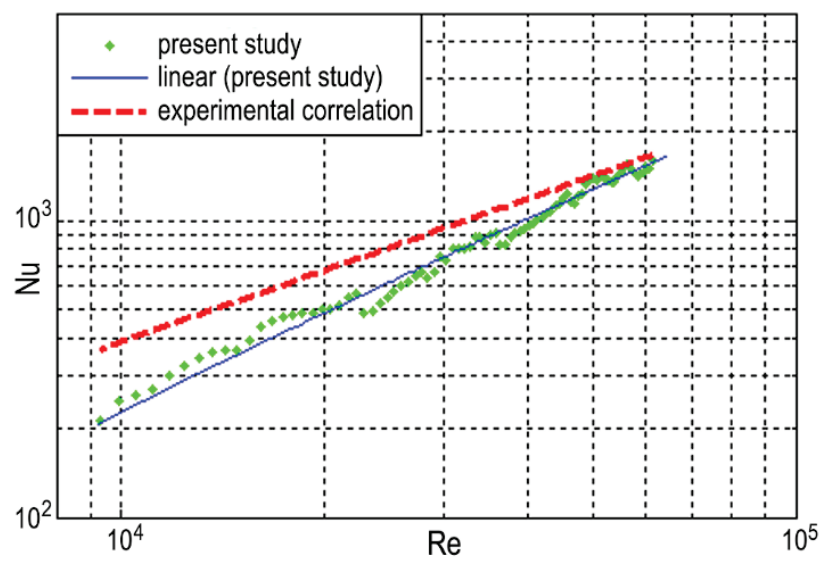

Figure 3 Comparison of Nusselt numbers vs. Reynolds numbers with an experimental correlation

\section{$5 \quad$ RESULTS AND DISCUSSION}

The results of the numerical analysis are presented in this section. Water temperature distributions in 3 different tube rows are shown in Figs. 4 to 6.

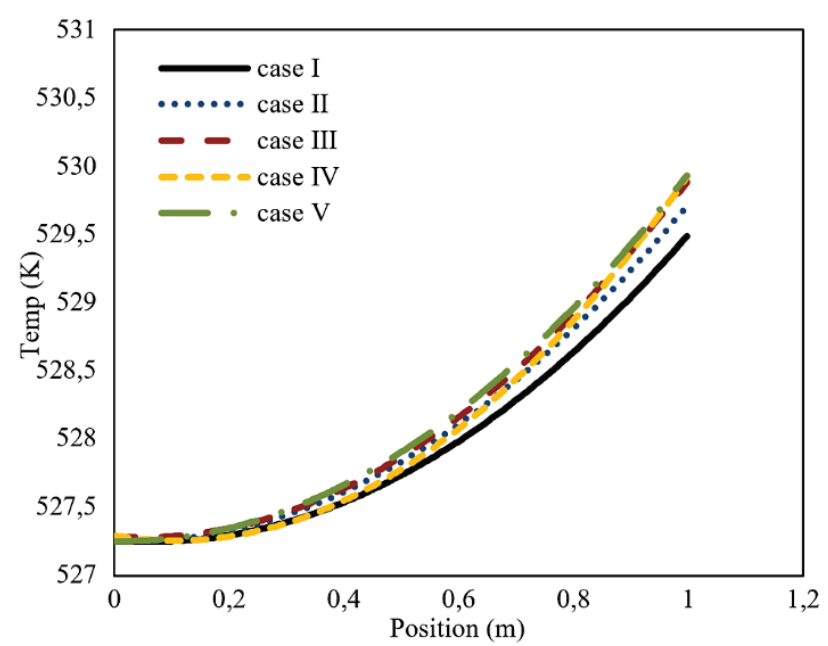

Figure 4 Water temperature distribution along the first tube row of economizers

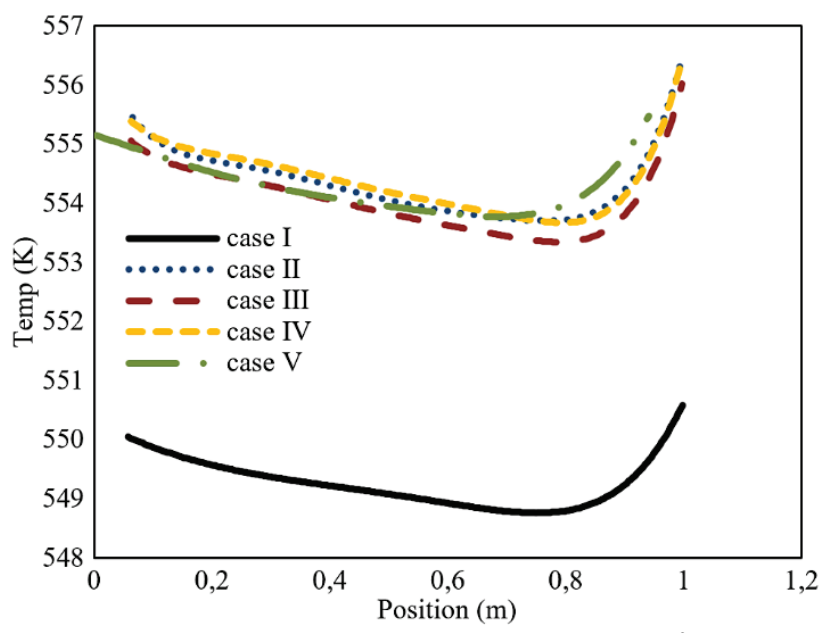

Figure 5 Water temperature distribution along the third tube row of economizers 


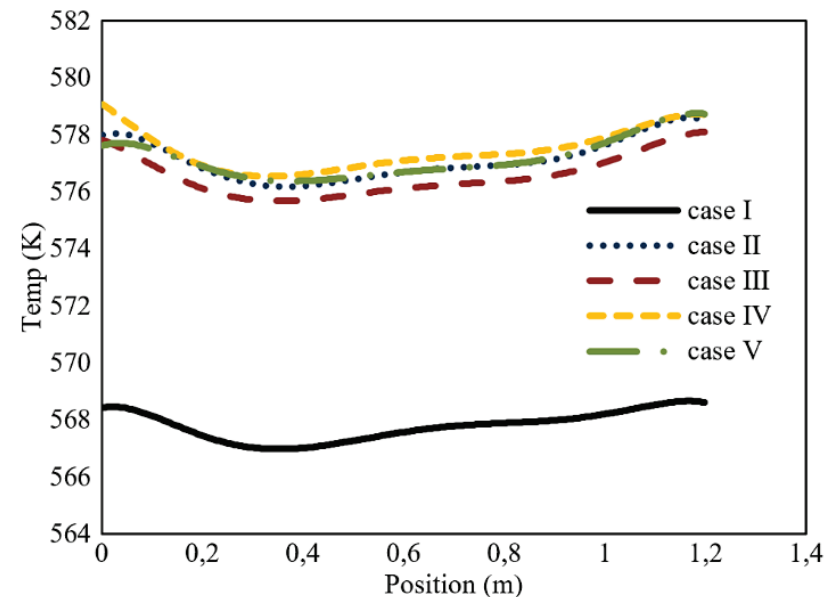

Figure 6 Water temperature distribution along the last tube row of economizers

Water temperature difference between bare tube economizer (case I) and finned-tube economizers (case II to $\mathrm{V}$ ) along the first, the third and the last tube row are less than $0,2 \%, 2,0 \%$ and $4,0 \%$ respectively. Generally, the finned-tube economizer with fin spacing value of $21 \mathrm{~mm}$ has the most water temperature enhancement in all tube rows compared to the other cases. The finned-tube economizers with fin spacing value of 15 and $24 \mathrm{~mm}$ have approximately the same water temperature enhancement in all tube rows. The finned-tube economizer with fin spacing value of $18 \mathrm{~mm}$ has the lowest water temperature enhancement compared to the other finned-tube economizers. Inlet and outlet water temperatures are shown in Tab. 2 for all cases.

Table 2 inlet and outlet water temperature for each case

\begin{tabular}{|c|c|c|c|c|c|}
\hline Case number & I & II & III & IV & V \\
\hline $\begin{array}{c}\text { Inlet water } \\
\text { temperature (K) }\end{array}$ & 527,0 & 527,0 & 527,0 & 527,0 & 527,0 \\
\hline $\begin{array}{c}\text { Outlet water } \\
\text { temperature (K) }\end{array}$ & 571,0 & 581,5 & 581,0 & 582,5 & 581,5 \\
\hline
\end{tabular}

Case IV has the highest outlet water temperature. By attaching circular fins to the tubes of economizers, outlet water temperature is increased up to $4,0 \%$.

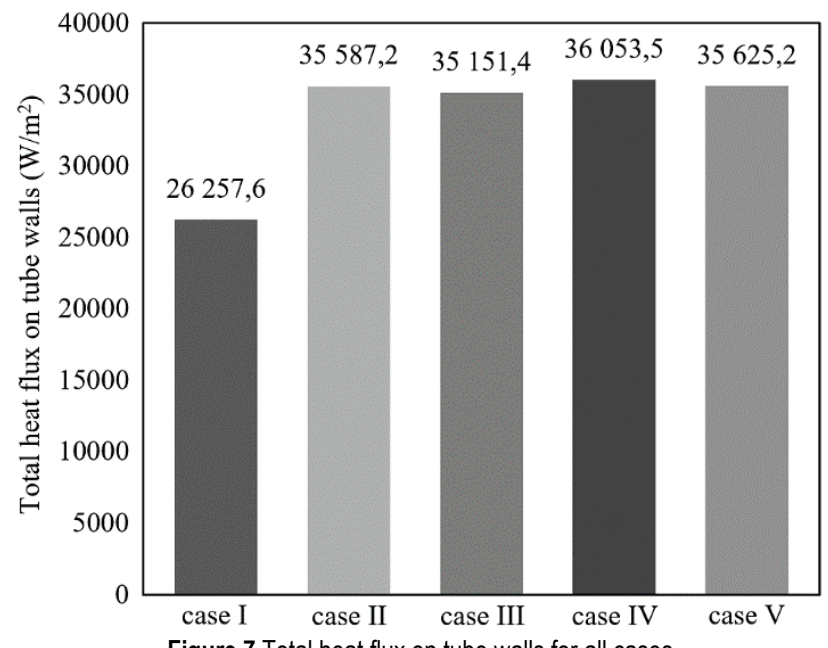

The total heat flux on tube walls is represented in Fig. 7 for all cases. The finned-tube economizer with fin spacing value of $21 \mathrm{~mm}$ (case IV) has the maximum heat flux as depicted in Fig. 7. Total heat flux is increased around $38,0 \%$ by attaching fins. The total heat flux difference between case II and V is around $0,1 \%$. The total heat flux in case IV is raised by $2,5 \%$ and $1,3 \%$ compared to case III and case II, respectively.

The total heat transfer rate is also represented in Fig. 8 for all cases. This amount is increased around $40,0 \%$ by using fins. The tube walls of finned-tube economizer with fin spacing value of $21 \mathrm{~mm}$ are received the biggest amount of heat transfer rate from hot flue gases. The total heat transfer rate difference between case $\mathrm{V}$ and case II is about $0,2 \%$. The total heat transfer rate in case IV is increased by $2,5 \%$ and $0,8 \%$ compared to case III and case II respectively.

According to the numerical results obtained from the present study, the finned-tube economizer with fin spacing value of $21 \mathrm{~mm}$ has the most optimized results relatively.

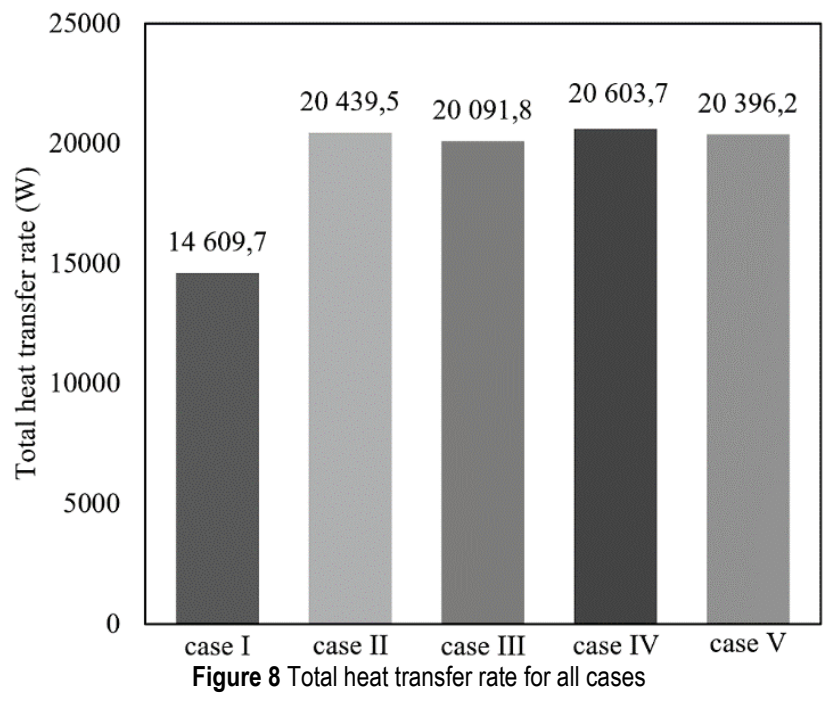

In order to analyze gas radiation effect on heat transfer in economizers, radiation transfer equation is coupled with energy equation and solved for all cases. The amounts of radiation heat transfer and radiation heat flux are displayed for bare tube economizer and one of the cases of finnedtube economizers in Figs. 9 to 12.

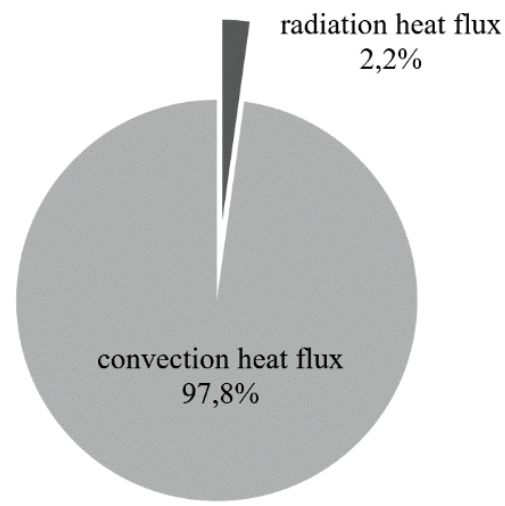

Figure 9 Percentage of convection and radiation heat flux on tube walls of bare tube economizer

The amount of radiation heat flux from the total heat flux is less than $3,0 \%$ for bare tube economizer as shown in Fig. 9. The amount of radiation heat transfer rate from the total heat transfer rate is also less than $3,0 \%$ for bare tube economizer as shown in Fig. 10. Figs. 11 and 12 show 
the radiation and convection heat flux and heat transfer rate for finned-tube economizers. Finned-tube economizers with different fin spacing values (case II to case V) have nearly the same results in this section. As depicted in Figs. 11 and 12 the dominant heat transfer mechanism is convection. Generally, gas radiation heat transfer contribution is less than $3,0 \%$ for all cases. Thus, convection has the most contribution in heat transfer for utility boiler economizers.

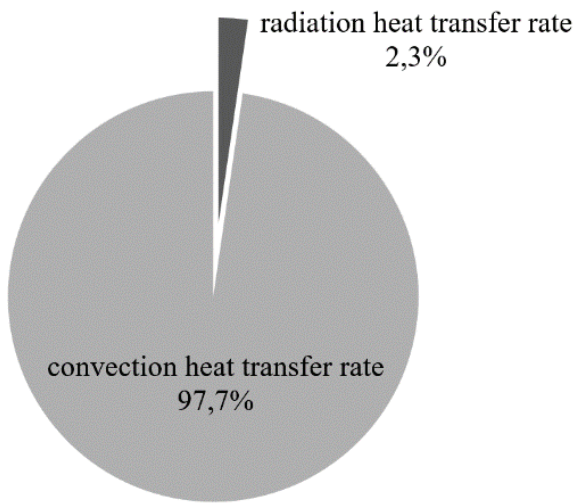

Figure 10 Percentage of convection and radiation heat transfer rate of bare tube economizer

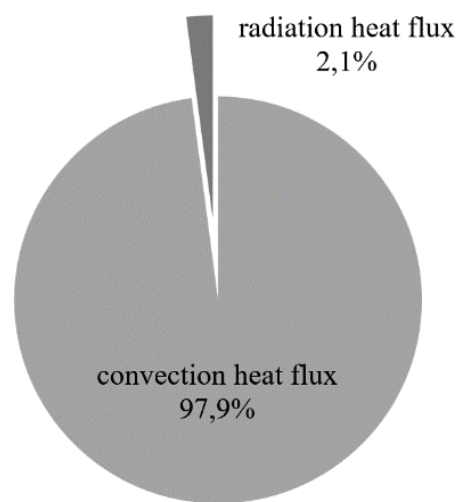

Figure 11 Percentage of convection and radiation heat flux on tube walls of finned-tube economizer

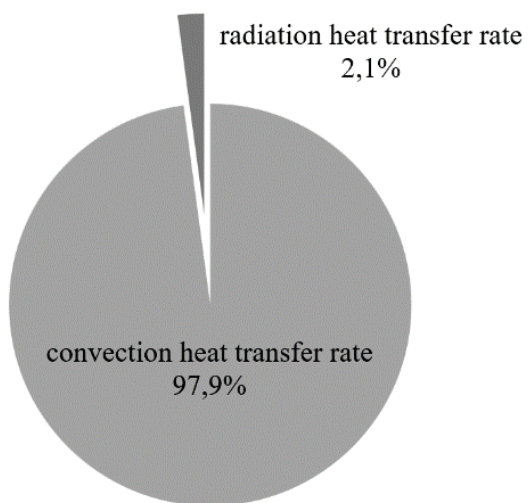

Figure 12 Percentage of convection and radiation heat transfer rate of finnedtube economizer

\section{CONCLUSION}

A numerical procedure has been developed to study fin spacing and gas radiation impacts on heat transfer in utility boiler economizers. The remarkable conclusions are:

- Validating the proposed numerical method was conducted through a comparison with experimental correlations and it was observed that the present numerical results are in a proper agreement with experimental results, Fig. 3.

- By attaching circular fins to the tubes of economizers, the feed water temperature along the tube rows was increased up to $4,0 \%$ in comparison with bare tube economizer, Figs. 4 to 6 .

- The highest outlet water temperature was achieved by using the economizer with fin spacing value of $21 \mathrm{~mm}$ (case IV), Tab. 2.

- The total heat flux on tube walls and the total heat transfer rate was estimated for all cases and it was observed that the total heat flux and the total heat transfer rate increased up to $38,0 \%$ and $40,0 \%$ respectively by using circular fins, Figs. 7 and 8 .

- The finned-tube economizer with fin spacing value of $21 \mathrm{~mm}$ (case IV) had the biggest amount of heat flux and heat transfer rate in comparison with the other cases.

- Radiation heat transfer contribution was less than 3,0\% for all cases.

\section{Nomenclature}

$d \quad$ Diameter $(\mathrm{m})$

$E \quad$ Internal energy (J)

$\vec{F} \quad$ External body forces (N)

$\vec{g} \quad$ Scceleration of gravity $\left(\mathrm{m} / \mathrm{s}^{2}\right)$

$h \quad$ Convective heat transfer coefficient $\left(\mathrm{W} / \mathrm{m}^{2} \mathrm{~K}\right)$

I Radiation intensity (W/sr)

$\vec{J}_{j} \quad$ Diffusion flux of species $j\left(\mathrm{~mol} / \mathrm{m}^{2} \mathrm{~s}\right)$

$k \quad$ Thermal conductivity $(\mathrm{W} / \mathrm{m} \cdot \mathrm{K})$

$L \quad$ Characteristic length (m)

$n \quad$ Refractive index

$\mathrm{Nu} \quad$ Nusselt number

$P \quad$ Pressure $(\mathrm{Pa})$

Pr Prandtl number

$\vec{r} \quad$ Position vector

Re Reynolds number

$s \quad$ Path length

$\vec{s} \quad$ Direction vector

$\vec{s}^{\prime} \quad$ Scattering direcion vector

$S_{\mathrm{h}} \quad$ Volumetric heat sources $(\mathrm{W} / \mathrm{kg})$

$t \quad$ Time (s)

$T \quad$ Temperature (K)

$u_{i} \quad$ Velocity component in the $x$ direction $(\mathrm{m} / \mathrm{s})$

$u_{j} \quad$ Velocity component in the $y$ direction $(\mathrm{m} / \mathrm{s})$

$u_{k} \quad$ Velocity component in the $z$ direction $(\mathrm{m} / \mathrm{s})$

$\vec{v} \quad$ Velocity vector $(\mathrm{m} / \mathrm{s})$

$x \quad$ Dimensional axial coordinate $(\mathrm{m})$

\section{Greek symbols}

absorptivity

$\delta_{i j} \quad$ Kronecker delta

$\rho \quad$ Density $\left(\mathrm{kg} / \mathrm{m}^{3}\right)$

$\sigma \quad$ Stefan-Boltzmann constant $5.669 \times 10^{-8}\left(\mathrm{~W} / \mathrm{m}^{2} \cdot \mathrm{k}^{4}\right)$

$\sigma_{\mathrm{s}} \quad$ Scattering coefficient

$\Omega^{\prime} \quad$ Solid angle (sr)

$\varepsilon \quad$ Emissivity

$\lambda$ Wavelength

$\mu \quad$ Dynamic viscosity (Pas)

$\varphi \quad$ Phase function 


$\begin{array}{ll} & \text { Subscripts } \\ \text { eff } & \text { Effective } \\ \mathrm{f} & \text { Film } \\ \mathrm{g} & \text { Gas } \\ \mathrm{i} & \text { Input } \\ \mathrm{i} & \text { Internal } \\ \mathrm{s} & \text { Surface } \\ \mathrm{t} & \text { Total } \\ \mathrm{w} & \text { Wall }\end{array}$

\section{REFERENCES}

[1] Steam: its Generation and Use. (2005). (41st ed.): The Babcock and Wilcox Company.

[2] Mudafale, K. P. \& Farkade, H. S. (2012). CFD Analysis of Economizer in a Tangential Fired Boiler. International Journal of Mechanical and Industrial Engineering, 2(4), 5155. Retrieved from http://interscience.in/ijmie.html

[3] Reddy, K. O., Srikesh, M., Kumar, M. K., \& Kumar, V. S. (2014). CFD analysis of economizer to optimize heat transfer. International Journal of Mechanical Engineering \& Technology (IJMET), 5(3), 66-76. Retrieved from http://www.iaeme.com/ijmet/index.Asp

[4] Holkar, R., Ramdas, B., Kunal, E., \& Haridas, B. (2014). Cfd Analysis of Gas Flow Behaviour in Economizer. Journal of Mechanical and Civil Engineering (IOSRJMCE), 11(6), 3139. https://doi.org/10.9790/1684-11643139

[5] Aziz, A., Siregar, P., Nazaruddin, Y., \& Bindar, Y. (2012). Improving the performance of temperature model of economizer using bond graph and genetic algorithm. International Journal of Engineering and Technology, 12(1), 57-61. Retrieved from http://ijens.org/ijet.html

[6] Wang, C., He, B., Yan, L., Pei, X., \& Chen, S. (2014). Thermodynamic analysis of a low-pressure economizer based waste heat recovery system for a coal-fired power plant. Energy, 65, 80-90. https://doi.org/10.1016/j.energy.2013.11.084

[7] Wang, C., He, B., Sun, S., Wu, Y., Yan, N., Yan, L., \& Pei, $X$. (2012). Application of a low pressure economizer for waste heat recovery from the exhaust flue gas in a $600 \mathrm{MW}$ power plant. Energy, 48(1), 196-202. https://doi.org/10.1016/j.energy.2012.01.045

[8] Patil, A., Baviskar, P., Sable, M., \& Barve, S. (2011). Optimization of economiser design for the enhancement of heat transfer coefficient. International Journal of Applied Research in Mechanical Engineering, 1(2), 52-57. Retrieved from http://interscience.in/ijarme.html

[9] Yang, D. K., Lee, K. S., \& Song, S. (2006). Fin spacing optimization of a fin-tube heat exchanger under frosting conditions. International Journal of Heat and Mass Transfer, 49(15-16), 2619-2625. https://doi.org/10.1016/j.jijheatmasstransfer.2006.01.016

[10] Bilir, L., İlken, Z., \& Erek, A. (2012). Numerical optimization of a fin-tube gas to liquid heat exchanger. International Journal of Thermal Sciences, 52, 59-72. doi: https://doi.org/10.1016/j.ijthermalsci.2011.09.010

[11] Čarija, Z., Franković, B., Perčić, M., \& Čavrak, M. (2014). Heat transfer analysis of fin-and-tube heat exchangers with flat and louvered fin geometries. International journal of refrigeration, 45, 160-167. https://doi.org/10.1016/j.jirefrig.2014.05.026

[12] Chen, H. T., Chou, J. C., \& Wang, H. C. (2007). Estimation of heat transfer coefficient on the vertical plate fin of finnedtube heat exchangers for various air speeds and fin spacings. International Journal of Heat and Mass Transfer, 50(1-2), 45-57. https://doi.org/10.1016/j.ijheatmasstransfer.2006.06.038

[13] Mon, M. S. \& Gross, U. (2004). Numerical study of finspacing effects in annular-finned tube heat exchangers.
International Journal of Heat and Mass Transfer, 47(8-9), 1953-1964.

https://doi.org/10.1016/j.ijheatmasstransfer.2003.09.034

[14] Pongsoi, P., Pikulkajorn, S., \& Wongwises, S. (2014). Heat transfer and flow characteristics of spiral fin-and-tube heat exchangers: A review. International Journal of Heat and Mass Transfer, 79, 417-431. https://doi.org/10.1016/j.ijheatmasstransfer.2014.07.072

[15] Romero-Méndez, R., Sen, M., Yang, K., \& McClain, R. (2000). Effect of fin spacing on convection in a plate fin and tube heat exchanger. International Journal of Heat and Mass Transfer, 43(1), 39-51. https://doi.org/10.1016/S0017-9310(99)00120-9

[16] Sadeghzadeh, H., Ehyaei, M. A., \& Rosen, M. A. (2015). Techno-economic optimization of a shell and tube heat exchanger by genetic and particle swarm algorithms. Energy Conversion and Management, 93, 84-91. https://doi.org/10.1016/j.enconman.2015.01.007

[17] El-Sayed, M., Sun, T., \& Berry, J. (2005). Shape optimization with computational fluid dynamics. Advances in Engineering Software, 36(9), 607-613. https://doi.org/10.1016/j.advengsoft.2005.03.009

[18] Khan, W. A., Culham, J. R., \& Yovanovich, M. M. (2006). Convection heat transfer from tube banks in crossflow: Analytical approach. International Journal of Heat and Mass Transfer, 49(25-26), 4831-4838. https://doi.org/10.1016/j.ijheatmasstransfer.2006.05.042

[19] Kakaç, S., Liu, H., \& Pramuanjaroenkij, A. (2012). Heat Exchangers: Selection, Rating, and Thermal Design: CRC Press. https://doi.org/10.1201/b11784

[20] Taler, D. \& Taler, J. (2009). Simplified analysis of radiation heat exchange in boiler superheaters. Heat Transfer Engineering, 30(8), 661-669. https://doi.org/10.1080/01457630802659953

[21] Moghari, M., Hosseini, S., Shokouhmand, H., Sharifi, H., \& Izadpanah, S. (2012). A numerical study on thermal behavior of a D-type water-cooled steam boiler. Applied Thermal Engineering, 37, 360-372. https://doi.org/10.1016/j.applthermaleng.2011.11.049

[22] Van Wylen, G. J., Sonntag, R. E., \& Borgnakke, C. (1998). Fundamentals of classical thermodynamics (5th ed.): John Wiley \& Sons.

[23] Ganapathy, V. (2003). Industrial boilers and heat recovery steam generators: Marcel Dekker Inc. https://doi.org/10.1201/9780203910221

[24] Howell, J. R., Menguc, M. P., \& Siegel, R. (2010). Thermal Radiation Heat Transfer: CRC Press. Retrieved from https://www.crcpress.com/

[25] Bergman, T. L., Incropera, F. P., DeWitt, D. P., \& Lavine, A. S. (2011). Fundamentals of heat and mass transfer: John Wiley \& Sons.

[26] Elliott, T. C., Chen, K., \& Swanekamp, R. (1997). Standard handbook of powerplant engineering: McGraw-Hill Professional.

[27] Wagner, W., \& Kretzschmar, H. J. (2007). International Steam Tables-Properties of Water and Steam based on the Industrial Formulation IAPWS-IF97: Springer Science \& Business Media. https://doi.org/10.1007/978-3-540-74234-0

[28] Kakaç, S., Shah, R. K., \& Aung, W. (1987). Handbook of single-phase convective heat transfer: John Wiley \& Sons Inc. 


\section{Contact information:}

\section{Azad HAMZEHPOUR, MSc}

Corresponding author

Department of Mechanical Engineering

Science and Research Branch, Islamic Azad University,

Daneshgah Blvd, Simon Bulivar Blvd, Tehran, Iran

E-mail 1: azad.hamzehpour@gmail.com

E-mail 2: azad.hamzehpour@srbiau.ac.ir

Cyrus AGHANAJAFI, PhD, Professor

Department of Mechanical Engineering,

Faculty of Mechanical Engineering,

K. N. Toosi University of Technology,

No. 7, Pardis St, Molla Sadra Ave, Vanak Sq, Tehran, Iran

E-mail: aghanajafi@kntu.ac.ir

Hossein SHOKOUHMAND, PhD, Professor

Corresponding author

School of Mechnical Engineering

College of Engineering, University of Tehran,

Jalal-e-Al-e-Ahmad Hwy, North Kargar St, Tehran, Iran

E-mail: hshokoh@ut.ac.ir

Mohammad NAJAFI, PhD, Associate Professor

Department of Mechanical Engineering,

Science and Research Branch, Islamic Azad University,

Daneshgah Blvd, Simon Bulivar Blvd, Tehran, Iran

E-mail: najafi@srbiau.ac.ir 